\begin{tabular}{|c|c|c|}
\hline$s t$ & $\begin{array}{l}\text { CARADDE: Jurnal Pengabdian Kepada Masyarakat } \\
\text { https://journal.ilininstitute.com/index.php/caradde } \\
\text { Volume 1 | Nomor 2 | Februari |2019 } \\
\text { e-ISSN: } 2621-7910 \text { dan p-ISSN: } 2621-7961 \\
\text { DOI: https://doi.org/10.31960/caradde.v1i2.62 }\end{array}$ & $\begin{array}{l}\text { Iin } \\
\text { CARADDE }\end{array}$ \\
\hline
\end{tabular}

\title{
Pengembangan Kompetensi Konselor Melalui Pelatihan Konseling Motivational Interviewing (MI) Berbasis Local Wisdom Budaya Jawa
}

\author{
Dwi Yuwono Puji Sugiharto ${ }^{1}$, Sigit Hariyadi ${ }^{2}$, Zakki Nurul Amin ${ }^{3}$, Mulawarman ${ }^{4}$, \\ Muslikah ${ }^{5}$, Edwindha Prafitra Nugraheni ${ }^{6}$
}

Keywords :

Kompetensi Konselor; Motivational Interviewing;

Budaya Jawa.

\section{Corespondensi Author}

Bimbingan dan Konseling, Universitas Negeri Semarang

Gedung A2 lantai 1 FIP Universitas

Negeri Semarang Kampus Sekaran,

Gunungpati, Kota Semarang

Email:

dypsugiharto@mail.unnes.ac.id

\section{History Artikel}

Received: Oktober-2018;

Reviewed: November-2018;

Accepted: November-2018

Published: Februari-2019
Abstrak. Kompetensi profesional Guru BK yang senantiasa perlu ditingkatkan adalah menguasai kerangka teoretik dan praksis bimbingan dan konseling. Tujuan kegiatan pengabdian kepada masyarakat ini adalah untuk meningkatkan kompetensi profesional guru BK di Kota Salatiga melalui pelatihan konseling motivational interviewing (MI) berbasis local wisdom budaya Jawa. Kegiatan pelatihan ini dilakasanan kepada 40 peserta selama dua hari tatap muka pada tanggal 31 Juli dan 1 Agustus 2018. Berdasarkan hasil analisis menggunakan margin mean dipahami bahwa ada peningkatan pemahaman peserta pelatihan dengan rentang margin skor 1,8. Pelatihan ini memberikan implikasi bagi guru BK untuk menerapkan pendeketan konseling MI ketika pemberian layanan konseling di sekolah.

\section{PENDAHULUAN}

Rendahnya mutu pelayanan pendidikan saat ini salah satunya disebabkan oleh distorsi budaya yang lebih mengedapan aspek rasionalitas dan inovasi dari pada pencerdasan manusia dan pendidikan budi perkeri luhur. Pendidikan seakan menciptakan manusia dengan intelektual yang tinggi namun tanpa emosi, jiwa sosial dan nilai humanis (Galus, 2015)

Persoalan ini menjadi problematikan tersendiri bagi Guru BK/Konselor sebagai pelaku profesional kesehatan mental disekolah. Konsep budaya dan teori barat yang menjadi acuan kadang kala menjadi penghambat sekaligus mengikis akar budaya setempat. Konsep teori dari barat tersebut perlu disesuaikan dengan keadaan budaya setempat.

Nilai budaya setempat hendaknya menjadi jiwa dari pendidikan. Baik dalam kacamata pendidikan maupun praktik pelayanan konselig nilai budaya lokal hendaknya dapat menjadi sebuah upaya dalam internalisasi penguatan nilai karakter pada peserta didik (Tilaar, 2000).

Hal ini juga menjadi tinjaun tersediri mengingat petingnya seorang konselor untuk memahami pengaruh konteks lingkungan (etnisitas, identitas etnis) dalam pembentukan sikap diri siswa dalam pemberian layanan konseling (Amin dkk., 2017). Persoalan ini disadari karena kondisi demografi indonesia yang beragam membuat faktor budaya menjadi konstruk penting dalam pelayanan 
konseling di sekolah (Saraswati, 2016).

Salah satu kompetensi profesional yang perlu dimiliki oleh konselor adalah menguasai kerangka teoretik dan praksis bimbingan dan konseling. Hal ini seperti yang diamanahkan pula dalam Permendiknas no.27 tahun 2008 mengenai standar kualifikasi dan kompetensi konselor. Salah satu kompetensi yang dapat dibentuk agar konselor dapat menjalankan konseling dengan profesional adalah pengaplikasian konseling Motivational Interviewing.

Konseling Motivational Interviewing (MI) merupakan konseling dengan metode memberikan petunjuk, berfokus ke klien guna meningkatkan motivasi instrinsik guna merubah pemahaman dan penyelesaian ambivalensi antara perilaku saat ini dengan tujuan dan nilai-nilai di masa datang (Harijanto, Rudijanto, \& Alamsyah, 2015). Disisi lain dijelaskan pula bahwa MI bukanlah sebuah teknik melainkan lebih kepada gaya semangat fasilitatif/fasilitator untuk membangun hubungan interpersonal dengan konseli (Miller \& Rollnick, 2012).

Abivalensi dan resistensi adalah hal yang wajar terjadi kepada siapa saja. Hampir saat individu dihadapkan pada sebuah pengambilan keputusan akan dihadapkan dengan abivalensi atau ketidakpastian yang utuh apalagi untuk berubah. Hal inilah yang menjadi salah satu dasar dari pendekatan MI.

Pendekatan MI memahami motivasi sebagai suatu proses atau kondisi kesiapan untuk berubah (a state of readiness to change) sehingga tujuan treatment adalah memfasilitasi klien dalam membangun tingkat kesiapan mereka untuk menapaki tahap demi tahap perubahan. Prinsip konseling MI berfokus pada express empathy, support selfefficacy, roll with resistance, dan develop discrepancy (Miller \& Rollnick, 2012)..

Pada pelatihan ini, konseling MI diterapkan dengan basis kearifan lokal budaya Jawa. Penggunaan nilai-nilai budaya lokal jawa dalam pendekatan konseling MI semisal "(tepo seliro), pemaafan (ora popo), ora kemrungsung (sabar), sikap pener tur bener (tepat dan benar)" mampu menjadi bentuk insight tersendiri bagi konseli untuk menemukan diri secara baik.

Konsep ini mampu menjadi motivasi sekaligus petunjuk bagi konseli dalam menyelesaikan masalah yang dihadapi.
Penerapan nilai budaya dalam konseling menjadi upaya bentuk pengembangan inovasi layanan yang cukup efektif dalam memberikan pelayanan kepada siswa baik dalam peningkatanan sikap sosial maupun pelayanan karir (Amin, Wibowo, dan Nusantoro, 2014; Silondae, 2013; Surya, 2013)

Pengembangan profesionalisme konselor sekolah melalui pelatihan konseling pendekatan MI berbasis local wisdom budaya Jawa diharapkan dapat memenuhi harapan konselor lapangan secara praktis dan pengembangan nilai konseptual secara teoritis dalam upaya perbaikan dan peningkatan kualitas pelayanan konseling disekolah.

Dalam hal ini pada pelaksanaan konseling MI maka dalam tahapan maupun tekniknya didasari dengan nilai-nilai budaya Jawa (tepo seliro, gederumongso, sumeleh, pemaafan (ora popo), ora kemrungsung (sabar), sikap pener tur bener). Pelatihan ini harapannya dapat memberikan kontribusi pada internalisasi nilai-nilai budaya Jawa baik pada konseli maupun konselor.

\section{METODE}

Kegiatan pengabdian pada masyarakat ini dilaksanakan 3 tahap yaitu: identifikasi peserta, pelaksanaan pelatihan, dan evaluasi pelatihan. Tahap identifikasi peserta dilakukan dengan menseleksi guruguru bimbingan konseling yang belum menguasai Konseling MI.

Proses kegiatan pelatihan dilaksanakan selama 2 hari tatap muka dan 2 minggu non tatap muka. Dalam kegiatan tatap muka 2 hari, peserta mendapatkan pelatihan penuh selama 10 jam per hari. Pelatihan dilaksanakan di SMP Negeri 2 Salatiga sebagai tuan rumah kegiatan. dihadiri 40 peserta yang dibagi menjadi 2 kelas dengan masing-masing 20 orang tiap kelas.

Tahap pelaksanaan diawali dengan ekspositori dan tanya jawab tentang materi kegiatan dan diskusi mendalam tentang materi pelatihan. Dilanjutkan dengan praktik pelatihan konseling MI dengan metode peer konseling. Tahap evaluasi dilaksanakan melalui hasil guru BK atau konselor tatkala melakukan layanan konseling.

Indikator yang digunakan untuk 
mengevaluasi keberhasilan pelatihan ini meliputi: (1) Tepat tatkala melaksanakan konseling MI berbasis local wisdom budaya jawa, (2) Peer observasi dari sesama praktikan (konselor) lain yang melaksanakan pelatihan sesuai indikator layanan, (3) Hasil analisis dan evaluasi dari layanan konseling oleh pelatih sesuai indikator layanan.

Sedangkan proses non tatap muka dilakukan kepada peserta melalui email dan komunikasi pesan lain untuk melihat perkembangan dan pengaplikasian hasil pelatihan yang dilakukan. Sesi non tatap muka diakhiri dengan kegiatan perekaman sesi atau kegiatan konseling melalui verbatim konseling oleh peserta. Setiap verbatim yang dibuat dilakukan analisis dan diberikan balikan agar dapat dipelajari dan dijadikan masukan bagi peserta.

\section{HASIL DAN PEMBAHASAN}

Tabel 1. Perbadingan Hasil Pre dan Pos Tes

\begin{tabular}{ccc}
$\begin{array}{c}\text { Rerata Pre } \\
\text { Tes }\end{array}$ & $\begin{array}{c}\text { Rerata Pos } \\
\text { Tes }\end{array}$ & $\begin{array}{c}\text { Margin } \\
\text { Skor }\end{array}$ \\
\hline 3,5 & 5,3 & 1,8 \\
\hline
\end{tabular}

Berdasarkan data hasil pre dan pos tes pada tabel 1. Dapat kita katakan bahwa terjadi peningkatan pemahaman peserta sebelum mendapatkan pelatihan dan sesudah mendapatkan pelatihan dengan margin skor 1,8 .

Hasil peningkatan pemahaman ini tidak hanya berkisar pada pemahaman secara kognitif akan tetapi diikuti dengan peningkatan keterampilan praktik konseling yang baik dilihat dari kegiatan peer konseling selama proses tatap muka serta evaluasi catatan verbatim konseling yang dilakukan selama proses non tatap muka. Peneliti tentunya berharap hasil ini bukan sementara tetapi terus berkelanjutan dalam menjalankan kegiatan pemberian layanan konseling di Sekolah.

Sebagai mana disampaikan pada bagian metode bahwa dalam kegiatan pelatihan dibagi menjadi 2 bagian yaitu tatap muka dan non tatap muka. Pada bagian tatap muka sendiri dilakukan 2 proses pembelajaran yaitu diskusi dan brainstorming yang diikuti dengan praktik simulasi terbimbing dan kegiatan peer counseling/peer teaching.
Pada sesi diskusi dan brainstorming peserta nampak antusias karena sebagian peserta beru pertama kali mengenal akan pendekatan konseling yang dijadikan tema dalam pelatihan ini. Hal ini cukup senada dengan apa yang dipahami bahwa nilai novelty atau kebaharuan dalam pembelajaran akan menjadi daya tarik tersediri bagi peserta latih/pembelajar. Disisi lain Salatiga sebagai salah satu kota dengan keragaman etnis yang tinggi menjadikan nilai jual tersendiri akan sebuah bentuk pelatihan denga tema basis budaya local sebagaimana diangkat dalam basis pendekatan yang diajarkan.

Pada sisi proses kegiatan pelatihan ini menggunakan metode peer counseling/teaching antar peserta sehingga memiliki pemahaman maupun pemecahan dalam menelaah pendekatan MI. Hal ini sejalan dengan apa yang dipahami bahwa metode peer memiliki hasil yang cukup efektif bahkan tidak jauh berbeda dengan hasil penilaian yang dilakukan oleh pengajar (Falchikov \& Goldfinch, 2000). Sejalan dengan hal ini hasil konsep peer juga terbukti efektif dalam rangka pembelajaran konseling dalam meningkatkan kemampuan peserta latih dalam pengembangan kompetensi konseling yang dimiliki (Muslikah, Hariyadi, \& Amin, 2016).

Sebagaimana yang dapat dilihat pada kondisi awal pelatihan (pre-tes) bahwa hasil pre-tes dan pos-tes menunjukkan bahwa kondisi pemahaman konseling motivational interviewing (MI) para guru BK atau konselor relatif rendah. Dengan demikian pola-pola pembelajaran penguatan konseling MI belum sepenuhnya terkuasai oleh calon guru BK atau konselor apalagi ketika mereka menjadi praktisi di sekolah.

Pada hasil pos test terjadi peningkatan rerata skor dengan margin 1,8. Hal ini manjadi poin yang cukup baik sebagai awal perubahan yang dilakukan oleh peserta. Pengalaman dan pemahaman baru yang diterima diharapkan mampu menjadi pemicu yang baik bagi peubahan komptensi konselor atau guru BK di sekolah agar menjadi lebih baik dalam pemberian layanan kepada siswa. Peserta menuturkan bahwa proses pelatihan yang dilaksanakan tatap muka selama 2 hari berjalan efektif salah satunya karena supervisor yang intens dalam membimbing praktik. 


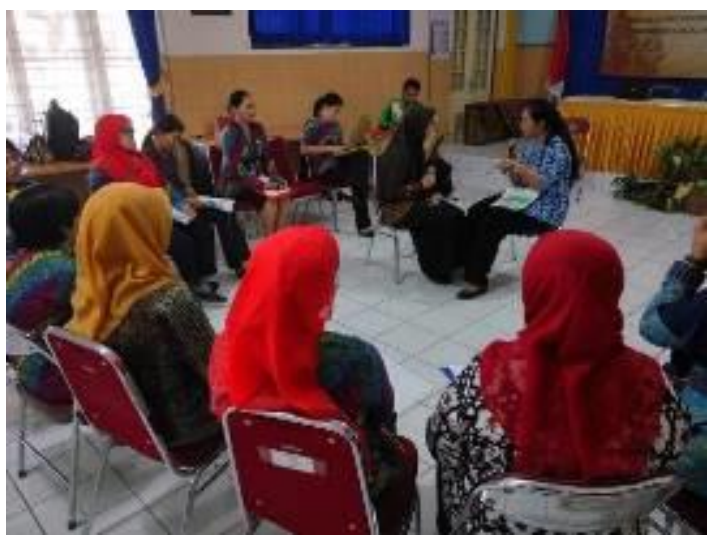

Gambar 1. Peraktik Peer-Counseling

\section{SIMPULAN DAN SARAN}

Simpulan yang dapat diperoleh dari pelaksanaan program pengabdian kepada masyarakat Pengembangan Kompetensi Profesional bagi Guru BK/Konselor Melalui Pelatihan konseling motivational interviewing (MI) berbasis local wisdom budaya jawa antara lain adalah program kegiatan pengabdian ini telah mencapai prosentase keberhasilan dari program yang telah direncakan. Sesuai dengan rencana kegiatan pengabdian beberapa hal yang telah berhasil dilaksanakan yakni perizinan internal lembaga, perizinan dan koordinasi dengan dinas dan MGBK SMP kota Salatiga, kegiatan pelatihan, serta kegiatan praktik di sekolah.

\section{DAFTAR RUJUKAN}

Amin, Z. N., Wibowo, M. E., Loekmono, L., Hariyadi, S., \& Isrofin, B. (2017). Ethnic Identity and Other-group Orientation on Javanese and Chinese Students. Proceeding. International Conference on Teacher Training and Education 2017, Solo, Indonesia.

Amin, Z.N, Wibowo, M.E., \& Nusantoro, E. (2014). Perbandingan orientasi karier siswa keturunan Jawa dengan siswa keturunan Tionghoa. Indonesian Jornal of Guidance and Counseling, 3(3), 8-16.

Galus, B. S. (2015). Mengembangkan Humanisme Jawa (Yogyakarta) dalam Pendidikan [Press release]

Harijanto, W., Rudijanto, A., \& Alamsyah, A. (2015). Pengaruh Konseling

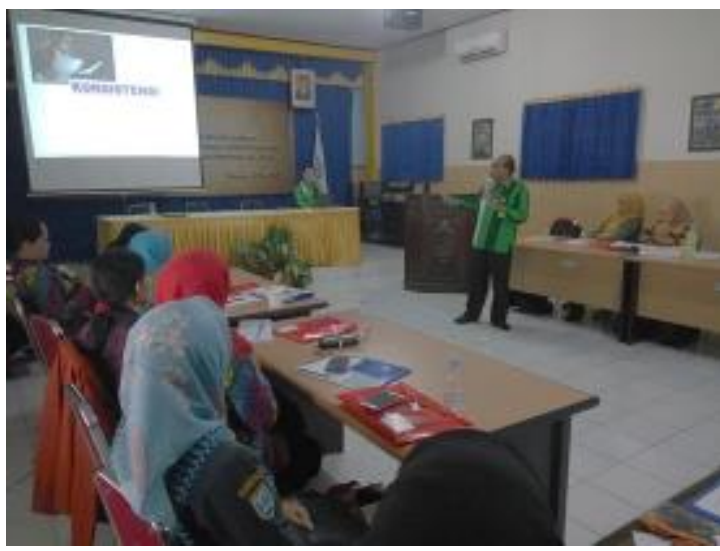

Gambar 2. Penyampaian materi kepada peserta

Motivational Interviewing terhadap Kepatuhan Minum Obat Penderita Hipertensi. Jurnal Kedokteran Brawijaya, 28(4), 354-353.

Miller, W. R., \& Rollnick, S. (2012). Motivational interviewing: Helping people change: Guilford press.

Muslikah, Hariyadi, S., \& Amin, Z.N. (2016). Pengembangan Model Peer Counseling Sebagai Media Pengalaman Praktik Konseling. Indonesian Jornal of Guidance and Counseling, 5(3), 48-52.

Saraswati, S., \& Amin, Z.N. (2016). Career Planning Attitude of Javanese and Chinese Student. Proceeding. Semarang State University International Conference on Counseling and Educational Psychology, Semarang, Indonesia.

Silondae, D. P. (2013). Model Bimbingan Kelompok Berbasis Nilai Budaya Suku Tolaki untuk Meningkatkan Keterampilan Sosial Siswa. Jurnal Bimbingan Konseling, 2(2).

Surya, M. (2013). Bimbingan Karir Berbasis Kearifan Lokal dan Nilai Keluarga: Pengembangan Karir Peserta Didik Melalui Pelayanan Konseling Bermartabat Dalam Membentuk Karakter Budaya Antar Bangsa Dalam Masyarakat Multikultural dan Modern. Makalah dalam Kongres XII dan Konvensi Internasional ABKIN, diselenggarakan tanggal, 14-16. 
Sugiharto, Hariyadi, Amin, Mulawarman, Muslikah, Nugraheni. Pengembangan Kompetensi Konselor

Tilaar, H. A. R. (2000). Paradigma baru pendidikan nasional: Rineka Cipta. 